American Journal of Agricultural and Biological Sciences 3 (1): 337-341, 2008

ISSN 1557-4989

(C) 2008 Science Publications

\title{
Proteins polymorphism of some populations of Lygeum spartum L. in Algeria
}

\author{
${ }^{1}$ Abderrezak Djabeur; ${ }^{1}$ Meriem Kaid-Harche and ${ }^{2}$ Douadi Khelifi \\ ${ }^{1}$ Biotechnology Department, Sciences faculty, University of Sciences and Technology, \\ Mohamed Boudiaf, P.O. Box. 1505, El Mnaouar, Oran, 31000, Algeria \\ ${ }^{2}$ Laboratory of genetics biochemistry and vegetable Biotechnology, Biology department, \\ Sciences faculty, Mentouri University, Constantine, 25000, Algeria
}

\begin{abstract}
Lygeum spartum L. represent a natural barrier in the Algerian high plateaus against the advances of sand and turning into a desert. This species has two levels of ploïdy (diploïd cytotype $2 n=16$ and polyploidy cytotype $2 n=40$ ). Protein profile of several populations of this species have inter and intra specific variability. The polymorphic bands observed in the intermediate and slow zone have a molecular weight (MW) of 25.6, 30.1, 31.2, 37.3, 40.4, 69.3 and $82.7 \mathrm{kDa}$. This polymorphism exists not only between the polyploids samples (well 1 to 7) and diploids (well 8 and 9), but also inside the polyploids populations. These results showed that modifications of the electrophoretic profile of Lygeum spartum were concomitant with climatic and geographical external factors.
\end{abstract}

Key words: Lygeum spartum, proteins, polymorphism, electrophoresis

\section{INTRODUCTION}

Lygeum spartum L. is a typical perennial grass (Poaceae) of the Mediterranean basin. It occupies a significant surface in the Algerian high plateaus approximately $30.000 \mathrm{Km}^{2^{[1]}}$. Lygeum spartum is regarded as a natural barrier slowing down wind erosion and the stranding dunaire ${ }^{[2]}$ thanks to its very developed roots system. This species constitutes a good example of adaptation to the dryness ${ }^{[3]}$, but also to the salinity, indeed its presence on salted grounds results from an adaptation of its roots system and more particularly of the unfolding or tripling of the endoderm $^{[4]}$. The presence of fibbers confers a significant role in the craft industry of the carpets, curtains, plaits ${ }^{[5]}$. The structural and architectural study of foliar fibres has shown the structural diversity of this tissue $^{[6]}$. Tests of obtaining paper pulp starting from foliar tissues made it possible to confirm that the Lygeum spartum is a paper plant ${ }^{[7,8]}$. This species is thus a plant of an ecological and economical interest. In this species, the chromosomes are large and their number is of $2 n=40$ [9]. Recent studies ${ }^{[10]}$ has shown the existence of two levels of ploïdy in this species in Algeria, it exists a diploïd cytotype $2 \mathrm{n}=16$ and a polyploid cytotype $2 n=40$, this last cytotype is very widespread.
The genetic variability of the populations is qualified of polymorphism. This term was introduced by $^{[11]}$, to indicate the coexistence in a population of two discontinuous forms or more.

We generally speaks about three types of polymorphism: Biochemical (affecting the structure of proteins and the enzymes), Chromosomic (affecting the structure of the chromosomes) and Molecular or nucleotidic (revealed in the DNA) ${ }^{[12]}$. Each alive being presents differences in its genome thus in its proteinic reserve compared to another alive being of another species-polymorphism inter specific, or between individuals of the same species-polymorphism intra specific. Thus, by the richness in such or such protein; the presence or absence of such protein that is made proteinic polymorphism between such or such species or under species. Biochemical Polymorphism (proteins) by a mono-dimensional electrophoresis on a polyacrylamide gel. This technique makes it possible to separate the proteins negatively charged, thanks to an electric field. The separation speed depends of the molecular mass of each protein, the low molecular weight proteins migrate more quickly than proteins of higher molecular weight.

The aim of the present investigation was to understand if there is a proteinic polymorphism between several populations of Lygeum Spartum taken

Corresponding Author:

Abderrezak Djabeur, Biotechnology Department, Sciences faculty, Sciences and Technology University, Mohamed Boudiaf, P.O. Box. 1505, El Mnaouar, Oran 31000, Algeria Tel: $0021372859953 \quad$ Fax: 0021341469329 
from different areas in order to select interesting proteins and thereafter genes of the resistance to the dryness and salinity in these species for biotechnological applications.

\section{MATERIAL AND METHODS}

Material: The vegetable material used in this study are the caryopses of Lygeum spartum of several populations: Kristel $1(2 \mathrm{n}=40)$, Kristel $2(2 \mathrm{n}=40)$, Es-Senia $1(2 n=40)$, Es-Senia $2(2 n=40)$, Saïda $(2 n=40)$, Bayadh $(2 n=40)$, Bouira $(2 n=40)$, Kheiter $1(2 n=16)$, Kheiter $2(2 n=16))$.

For Es-Senia 1, Es-Senia 2 and Kristel 1, Kristel 2 we worked on the normal caryopses 1 and the caryopses badly formed 2 , to see whether the badly formation of the caryopses is genetic or not.

For Kheiter 1, Kheiter 2 we did the sampling within the same population, but at two distant places approximately $2 \mathrm{~km}$, to see the existence or not of a polymorphism intra specific.

For each population 20 caryopses, taken randomly from several tufts were perfectly crushed in a mortar in order to obtain flour which will be used for the extraction of total proteins.

\section{Methods}

Extraction of total proteins: The extraction was carried out according to the protocol of ${ }^{[13]}$ starting from the flour of the caryopses. It was carried out with a solution stock of extraction made up of: SDS (Sodium Dodecyl-Sulphate), which makes it possible to denature the proteins, glycerol which causes the weighing down of the proteins at the bottom of the well in the gel, Tris $1 \mathrm{M}$ which confers the $\mathrm{pH} 6.8$ and a colourings agent the Bromophenol Blue (for proteins detection). This method allows an extraction of the total proteins. Addition of the $\beta$ mercapto-ethanol makes it possible to break the disulphids links between the peptidic chains of the protein. Eppendorfs containing the samples and the solution of extraction were incubated in a regulated drying oven at $60^{\circ} \mathrm{C}$ during 2 hours to accelerate the denaturation of proteins. After a 10 minutes centrifugation at $600 \mathrm{~g}, 12 \mu \mathrm{l}$ of the supernatant were deposited in well of the electrophoresis gel (each well corresponds each population). In the last well $12, \mu \mathrm{l}$ of solution of the proteins markers we were (witness well), this one was allowed to determine the various molecular weights of proteins. We applied a monodimensional electrophoresis in the presence of the SDS, on a vertical polyacrylamide gel (SDS-PAGE) according to the method of ${ }^{[14]}$.

Preparation of the gel: The gel of separation is used at $\mathrm{T}=12.8 \%$, where $\mathrm{T}=$ acrylamide + bis-acrylamide for $100 \mathrm{ml}$ of solution ${ }^{[15]}$. Acrylamide gel $(35 \%) ; \mathrm{N}, \mathrm{N}$ methylen Bisacrylamide (2\%); Tris- $\mathrm{HCl}(1 \mathrm{M}, \mathrm{pH} 8.8)$; SDS $(10 \%)$ and distilled water. The reaction of polymerization is done in the presence of two catalysts: Ammonium Persulphate (APS) at $1 \%$ and Tetramethylen diamine (TEMED). The gel of concentration at $\mathrm{T}=2.8 \%$ has the same composition as the gel of separation except that the Tris- $\mathrm{HCl}$ is at pH 6.8 .

Electrophoresis Plug: After deposit of the sample, the electrophoresis tank (the two rooms superior and inferior) is filled with a sufficient volume of electrophoresis plug; this last is composed of Glycine, Tris and SDS. The migration is led with a current intensity of $80 \mathrm{~mA}$.

Coloration and discoloration of the gel: Once that the forehead of migration reaches the basal end of the gel of separation, this last is unmoulded and put under agitation during one night in a solution of colouring made up of TCA $60 \%$ Tri-chloroacétique acid and blue of coomassy R-250 (the gel of concentration is eliminated). Discolouration was done by repeated rinsings of the gel with water tap.

Discolourated gel is put in agitation in a $10 \%$ glycerol solution during one hour, then dried at the ambient temperature between two polyethylene sheets and can be thus preserved.

The electrophoretic diagram has been read according to the relative mobility and intensity of the bands. There is a linear relation between the logarithm of Molecular weight MW and the relative mobility of the bands (proteins), this allowed us to determine the MW of proteins starting from a calibration curve which was traced using the proteins markers of a known molecular mass: Phosphorylase B $97 \mathrm{kDa}$, Ovalbumin $45 \mathrm{kDa}$, Carbonic anhydrase $30 \mathrm{kDa}$, Trypsin inhibitor $20.1 \mathrm{kDa}$, provided by Amersham Pharmacia Biotech.

\section{RESULTS}

The electrophoregram reading consists to characterize each band detectable by its relative mobility compared to a pilot well (proteins markers Kit), by its presence or absence and concentration. This technique made it possible to detect proteinic differences between the various studied samples of the species Lygeum spartum.

The diversity of total proteins is estimated by a technique of distribution electrophoretic profile in zone, where we distinguished three zones with different mobility: slow, intermediate and fast zone Fig. 1.

The slow zone: While basing on the mobility and the molecular weight, it includes the bands which have a molecular weight which varies between 45 and $94 \mathrm{kDa}$. 
Am. J. Agri. \& Biol. Sci., 3 (1): 337-341, 2008

Table 1: Distribution of the polymorphic bands in the various populations (+: presence; -: absence; +/-: trace of band)

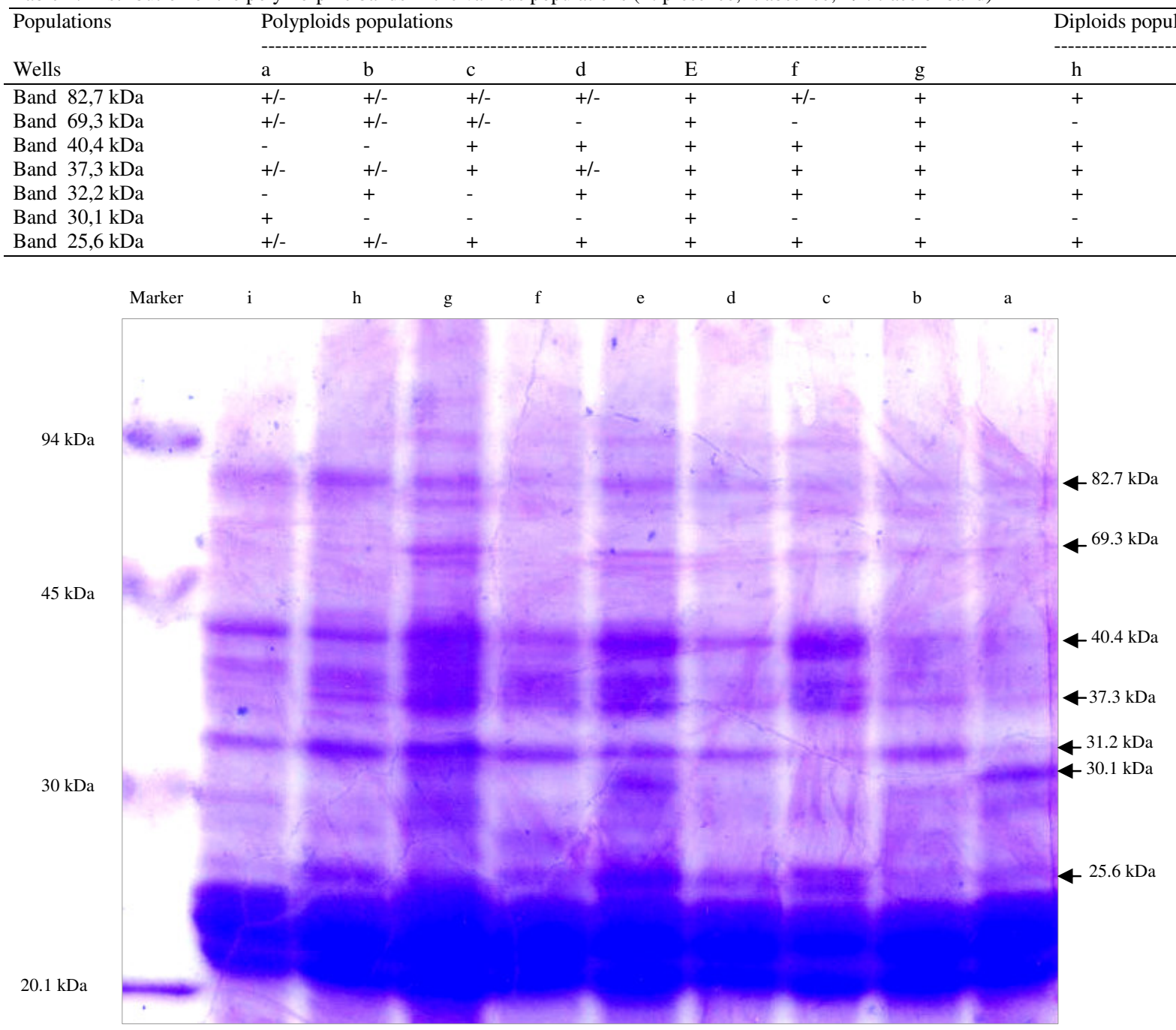

Fig. 1: Profile of a monodimensional electrophoresis of total proteins of the caryopses of several populations of Lygeum spartum on a polyacrylamide gel

a. Normal Kristel caryopses $(2 \mathrm{n}=40)$; b. Badly formed Kristel caryopses $(2 \mathrm{n}=40)$;

c. Normal Sebkha caryopses $(2 \mathrm{n}=40)$; d. Badly formed Sebkha caryopses $(2 \mathrm{n}=40)$;

e. Saida $(2 \mathrm{n}=40)$; f. El Bayadh $(2 \mathrm{n}=40) ;$ g. Bouira $(2 \mathrm{n}=40)$; h. Kheiter site $1(2 \mathrm{n}=16)$;

i. Kheiter site $2(2 n=16)$.

We will note the weak quantity of the bands with the low intensity in this zone.

The intermediate zone: This zone includes proteins having of the MW which vary between 45 and $24 \mathrm{kDa}$. These bands are the best separated, with a better resolution of the bands.

The fast zone: it includes the proteins which have MW vary between 24 and 14,4 $\mathrm{kDa}$. These bands are very concentrated; we could not distinguish a polymorphism in this zone.
Electrophoretic analysis of polymorphism: The polymorphic bands observed in the intermediate zone and the slow zone have a MW of 25.6, 30.1, 31.2, 37.3, 40,4 , of 69.3 and $82.7 \mathrm{kDa}$ (Fig. 1 and table 1). This polymorphism exists not only between the polyploids samples (well 1 to 7) and diploids (well 8 and 9), but also inside polyploids populations, the electrophoregrams variety according to the sampling station.

Much more, the proteinic profile can vary within the same station either according to the distance between the sampled tufts, or according to the character 
normal or badly formed of the caryopses. In the first case, we see that the two sampling carried out in Kheiter defer by the intensity of the band of $25.6 \mathrm{kDa}$. This last band is very thin, practically absent in site 2 of Kheiter. The physical distance of the samples taken within the same population showed modification of proteinic profile. In the second case, wells 1 (normal caryopses) and 2 (badly formed caryopses) coming from the population of Kristel present a very neat polymorphism in MW 30.1 and $31.2 \mathrm{kDa}$ bands (figure 1 and table 1). The same observation was obtained in population of the littoral (normal caryopses, well 3, and badly formed caryopses, well 4). Here, the difference was detected in 25.6 and $31.2 \mathrm{kDa}$ bands and concern also the $40.4 \mathrm{kDa}$ band. Thus, there was a relationship between bad formations of the caryopses and their proteinic profile.

\section{DISCUSSION AND CONCLUSION}

The electrophoretic analysis enabled us to detect differences of the proteinic profile within the populations of Lygeum spartum which constitute a polymorphism: each population defers from the others, either by the number of bands or by their intensity. The electrophoresis of proteins can reveal a polymorphism due only to the external factors, i.e. the genome is the same one but that it is expressed differently according to surrounding conditions'. According to ${ }^{[16}$ and 17$]$, the proteinic composition can be under the dependence of the genetic and agro climatic factors. Indeed ${ }^{[18]}$ showed that there exists, in the rye caryopses, a specific protein playing a role in the expression of the tolerance to the cold. According to ${ }^{[19]}$, each type of stress, either it is thermal, hydrous or saline produces a specific protein. At the tobacco, a saline stress reveals new proteinic bands, similar to those observed at the time of a thermal stress at the same species ${ }^{[20]}$. However, ${ }^{[21]}$ have also put in obviousness a proteinic polymorphism between the two polyploid populations of Lygeum spartum, El-Bayadh (arid zones) and Sebkha (half arid zones).

The bad formation of the caryopses can be related to genetic factors or external factors such as for example a bad exposure to the sun, a bad rock salt supply, an attack by insects... etc. These factors represent stresses which can modify the electrophoresis profile of the caryopses badly formed. Thus within the same population of $L$ spartum we can find a polymorphism intra specific due to the external factors, i.e. genetic stock is the same, but it is expressed differently.

\section{REFERENCES}

1. Le Houerou, H.N., 1995. Considérations biogéographiques sur les steppes arides du Nord de l'Afrique. Sécheresse, $6: 167-182$.

2. Aidoud, A. (1983). Contribution à l'étude des écosystèmes steppiques du Sud-Oranais (phytomasse, productivité primaire at application pastorales). Doct. 3ème Cycle, USTHB Alger 245p. + Annex.

3. Killian, C., 1948. Conditions édaphiques et relations des plantes indicatrices de la région Alfatière algérienne. Ann. Agr., 1:4-27

4. Kribi-Belabed, S. (1993). Contribution à l'étude morphologique du système racinaire du Sparte (Lygeum spartum L.) en relation avec la sécheresse et la salinité. Thesis of Magister. Univ. Oran, 72p. + Annex.

5. Mariano De Lapaz, G., 1876. Les spartes, les joncs, les palmiers et les pittes. Soc. Acclim., 419-493.

6. Harche, M., R. Chadli and A.M. Catesson, 1990. Diversity of cellulose micro fibril arrangement in the cell walls of Lygeum spartum leaves. Annals of Botany, 65: 79-86.

7. Chadli, R. (1990). Contribution à l'étude du Sparte (Lygeum spartum L.) : germination, croissance des feuilles, structure pariétale. Essai d'obtention de pâte papetière à partir des fibres foliaires. Thesis of Magister, Univ. Oran, 96p.

8. Chadli, R. and M. Harche, 1991. Obtention de pâte papetière à partir des fibres foliaires de (Lygeum spartum L.). In the 3rd International Workshop on plant polysaccharides structure and function, 19-21 September 1990, Le Croisic, France.

9. Tutin, T.C., V.H. Heywood and N.A. Burges, 1980. Flore Europea. Vol. V, "Monocotyledons" Cambridge University Press, Cambridge, U.K.

10. Benmansour, N. and M. Kaid-Harche, 2001. Etude caryologique de deux populations de Lygeum spartum L. de l'Ouest algérien. Bocconea, $13: 371-376$.

11. Ford E.B., 1940. Polymorphism and Taxonomy. In: The new systematic, Oxford.

12. Godon, B., 1985. Protéines végétales. eds. Tec. et Doc. Paris, 629p.

13. Payne, P.I. and K.G. Corfield, 1979. Subunit composition of glutenin wheat proteins isolated by gel filtration in a dissociating medium. Planta, 145: 83-88. 
14. Laemmli, U.K., 1970. Cleavage of structural protein during the assembly of the head of bacteriophage T4. Nature, 247: 680-685.

15. Marouf, A. (2001). Analyse instrumentale à l'usage des biologistes, 2nd eds. Dar el gharb. Oran, 280p.

16. Tanaka, K. and W. Bushuk,, 1972. Effect of protein content and wheat variety on solubility and electrophoretic properties of flour proteins. Cereal Chem., 49: 247-257.

17. Doekes, G.J. and L.M.J. Wennekes, 1982. Effect of nitrogen fertilization on quality and composition of wheat flour protein. Cereal Chem., 59: 276-278

18. Cloutier, Y., 1984. Changes of proteins patterns in winter rye following cold acclimation and desiccation stress. Can. J. Bot., 62: 366-371.
19. Schöffl, F., G. Baugmann, E. Raschke and M.W. Bevan, 1986. The expression of heat shock genes in higher plants. Philosophical transactions of the Royal Society, 314: 453-468, London.

20. Harrington, H.M. and D.M. Alm, 1988. Interaction of heat and salt shock in cultured Tobacco cells. Plant Physiol., 88: 618-625

21. Abdi, L. et F. Tahir, 2005. Etude morphologique et biochimique des infrutescences et des caryopses de Sparte (Lygeum spartum L.). Memorandum of engineer Univ. USTOMB, Oran, 70p. + Annex. 